\title{
Is there a relationship between shyness and English proficiency level of bilingual and monolingual EFL learners
}

\author{
Hamedreza Kohzadi ${ }^{1, *}$, Fatemeh Azizmohammadi ${ }^{2}$, Fatemeh Samadi ${ }^{3}$ \\ 1,2Department of English Language and Literature, College of English, \\ Arak Science and Research, Branch, Islamic Azad University, Arak, Iran \\ ${ }^{3}$ Department of TEFL, College of English, Arak Science and Research Branch, \\ Islamic Azad University, Arak, Iran \\ *E-mail address: hamedreza_kohzadi_usa@yahoo.com
}

\begin{abstract}
It would be mention that bilingualism can be defined in different ways. For example, Maleki (2011) asserted that individual level includes consecutive or simultaneous learning which involves the content of achievement, ability, language competence and proficiency. However, social level contains complex phenomena of minority and migrants and focuses some matters like domain and diglossia. These are useful in interpreting the various ways that linguistic resources are organized in multilingual communities. In these communities, there are some phenomena like transfer, borrowing, code switching and interference. The current study seeks to examine the effects of the role of shyness in English proficiency level of Bilingual EFL Learners in Komijan (in the province of Markazi) and Monolingual EFL learners in Arak (in the province of Markazi). The number of subjects were 98 and all of them were male .The age range of learners was 12 to 15. Thus, Revised Cheek and Buss Shyness Scale (RCBS) was used to measure the shyness level of both bilingual and monolingual learners. Results of the One-way ANOVA indicated that different level of shyness was not significant among bilingual and monolingual learners. It also indicated that bilingual students outperformed monolingual students in General English Proficiency.
\end{abstract}

Keywords: Monolingual and bilingual males; General English Proficiency; shyness

\section{INTRODUCTION}

\section{1. What is Bilingualism?}

The main purpose of this study was to investigate interactions between shyness and proficiency level of Bilingual and Monolingual EFL Learners. Thus, researchers first explain about bilingualism briefly and the importance of shyness.

As Maghsoudi (2010) has mentioned in his paper bilingualism is a difficult impression to define and there is no general agreement to do a limited informal conversation, but setting specific limitations on proficiency or representing comprehension of another speaker or how much the speaker in question is speaking is impossible.

Karbalaei (2010) expressed his idea about definition of bilingualism in this way: a bilingual person can speak more than one language. But defining bilingualism becomes more 
complicated when anybody thinks about the exact meaning of language and how it can be defined things like fluency.

Kalyani \& Sampath (2005) reported that bilingualism's effects on learning a second language can be considered as a universal phenomenon in a monoculture country such as India. So, this effect on cognitive process isn't problematic but it is important in determining situations that bilinguals are likely to retard or accelerate growth. Aa a matter of fact, the level of bilingual competency is emphasized as an intervening variable in mediating the effects of their bilingual experiences on cognition.

Merrikhi (2012) asserted that one of the most important issues is bilingual acquisition for investigators. So, there is a widespread discussion about the children of bilingual parents who are linguistically at risk and their brains will not be able to manage and it can be say that they will grow up - semi lingual, confused or retarded As a matter of fact fluency displayed by millions of bilingual and trilingual children all over the world. By the time bilingual children arrive in school like their monolingual peers reached the same stage of linguistic development. But the process of learning two languages is not exactly the same as the process of learning one.

Edwards (2003) first started his discussion by asking a question about the importance of bilingualism: Why should bilingualism (or multilingualism) be particularly important? After all, the majority of people in the world can use in more than one language and we know that it is monolingualism that is an aberration, a difficulty of the influential and a disease to be treated.

\section{2. The importance of shyness}

About the importance of shyness, as Tanveer (2007) said that "learners of English language often express some feelings like anxiety, stress or nervousness while learning to speak English Language and declare to have, a 'mental block' against learning English." On the other hand, Baş (2010) argued that: Shyness belongs to a particular category. For example, one such category sees shyness as a subjective experience which is presented as nervousness and apprehension in interpersonal encounters (Buss, 1980; Leary \& Schlenker, 1981; Zimbardo, 1977).

Buss (1980) defined shyness as an inhibition of expected social behavior followed by feelings of tension and awkwardness. So, shyness can be regarded as a social phenomenon, and a type of social anxiety. As Stockli (2002) pointed out: In a study that was done in the US about the relationship between gender and shyness, Caspi, Elder and Bem (1988) reported relationships between shyness in childhood and coping with various developmental tasks in adulthood.

This study basically attempted to answer the question about the effect of shyness on English proficiency level of bilingual and monolingual learners. Therefore the following hypotheses are formulated:

H1: Bilingual male learners are shyer than monolingual male learners.

$\mathrm{H} 2$ : Regarding the level of shyness in subjects, there would be significance difference between monolingual and bilingual males in General English proficiency.

\section{METHODOLOGY}

\section{1. Participant}

The initial sample of this study consisted of 98 students with the age range of 12 to 15 . They consisted of two groups 1) 48 monolingual students have been lived in Arak. 2) 50 
bilingual students have been lived in Komijan. Due to a background questionnaire some information about subjects were elicited, Group A included 5o male monolinguals and Group $\mathrm{B}$ included 45 male bilinguals.

\section{2. Instruments}

Different materials which were used in this study include:

\section{a) Background questionnaire}

The researchers used background questionnaire in order to elicit some information as: the subjects' full name, their age, name of their school and the language/languages they use. (See Appendix I)

\section{b) Revised cheek and buss shyness scale (RCBS)}

Revised Cheek and Buss Shyness Scale (RCBS) is one of the most commonly employed measures of dispositional shyness (Cheek \& Briggs, 1990). (See Appendix II)

\section{c) Language Proficiency Test (Transparent)}

It was used to determine students' levels of English proficiency. This test was composed of 30 questions about grammar, 10 questions about vocabulary and 10 questions for reading comprehension, totally it contained 50 questions. (See Appendix III)

Since English proficiency test scores are tabulated out of 50, each question had one score. All parts were in the form of Multiple-Choice questions. In order to make sure of the reliable proficiency test at the piloting stage, the test was given to 15 students, who were selected randomly, and its reliability was estimated through the K-R21 formula as .85, therefore the test was found reliable for the purpose of this study (Meihami, et al., 2013, 2014).

The total time allotted to the test was also determined at the pilot stage as 40 minutes. Duration of the test was estimated by calculating the time spent by the fastest and the slowest students in answering the test divided by 2 . Thus, the time allotted to the test was:

$$
\frac{50+30}{2}=40
$$

(See Appendix III)

\section{3. Procedures}

The following procedures were adopted in order to meet the objective of this study. Phase 1: The Background questionnaire was given to the subjects to fill them out. Phase 2: Revised cheek and buss shyness scale (RCBS) has taken to both male and female learners by researchers. The items are answered on a 5-point Likert scale. The scale items are written so as to tap into affective and behavioral aspects of shyness without referring to the desire to seek out or avoid social interactions $(\mathrm{r}=-.30)$ (Leary, 1991). Phase 3: The Transparent test was given to 98 male monolingual and bilingual students. They are male and female guidance school students who were monolingual and bilingual. Two groups of High and Low language proficiency levels were identified, that is, those whose scores were 1SD below the mean were taken as Low and those whose scores were 1SD above the mean as High level, making 98 students in total. 


\section{RESULTS AND DISCUSSION}

In order to analyze obtained data, the researchers computed them by means of the statistical package SPSS .The kinds of analyses that were used included one way ANOVA and independent sample's t-test to determine whether or not there is a difference in mean between the two groups - if it existed - was significant at the .05 level. So, statistical representation of the analyzed data is given in Table 1 and figurelas follow:

Table 1. Results of t-test and one-way ANOVA for mean scores on male monolinguals and male bilinguals in revised cheek and buss shyness scale

\begin{tabular}{|c|c|c|c|c|c|}
\hline Group & Number & Mean & $\begin{array}{c}\text { Standard } \\
\text { deviation }\end{array}$ & $\begin{array}{c}\text { Standard } \\
\text { error } \\
\text { mean }\end{array}$ & P value \\
\hline $\begin{array}{c}\text { Male } \\
\text { Monolinguals }\end{array}$ & 48 & 5.9 & 2.19 & 0.31 & \multirow{2}{*}{0.242} \\
\cline { 1 - 4 } $\begin{array}{c}\text { Male } \\
\text { bilinguals }\end{array}$ & 50 & 6.44 & 2.31 & 0.344 & \\
\hline
\end{tabular}

Regarding obtained mean, there's not a statistically significant difference between male monolinguals and male bilinguals in terms of shyness level $(p>0 / 05)$. Therefore the first hypothesis was rejected.

In order to see if the hypotheses of this study were approved or rejected, the one-way ANOVA and t-test statistics were calculated between the scores obtained by monolingual and bilingual subjects on the General English proficiency. Table 1 and figure 1 indicates mean proficiency scores of male monolinguals and male bilinguals in General English proficiency

Table 2. Results of t-test and one-way ANOVA for mean scores on male monolinguals and male bilinguals in General English proficiency.

\begin{tabular}{|c|c|c|c|c|c|}
\hline Group & Number & Mean & $\begin{array}{c}\text { Standard } \\
\text { deviation }\end{array}$ & $\begin{array}{c}\text { Standard } \\
\text { error } \\
\text { mean }\end{array}$ & P value \\
\hline $\begin{array}{c}\text { Male } \\
\text { monolinguals }\end{array}$ & 48 & 21.7 & 7.19 & 1.03 & 0.017 \\
\cline { 1 - 4 } $\begin{array}{c}\text { male } \\
\text { bilinguals }\end{array}$ & 50 & 25.14 & 6.82 & 0.965 & \\
\hline
\end{tabular}




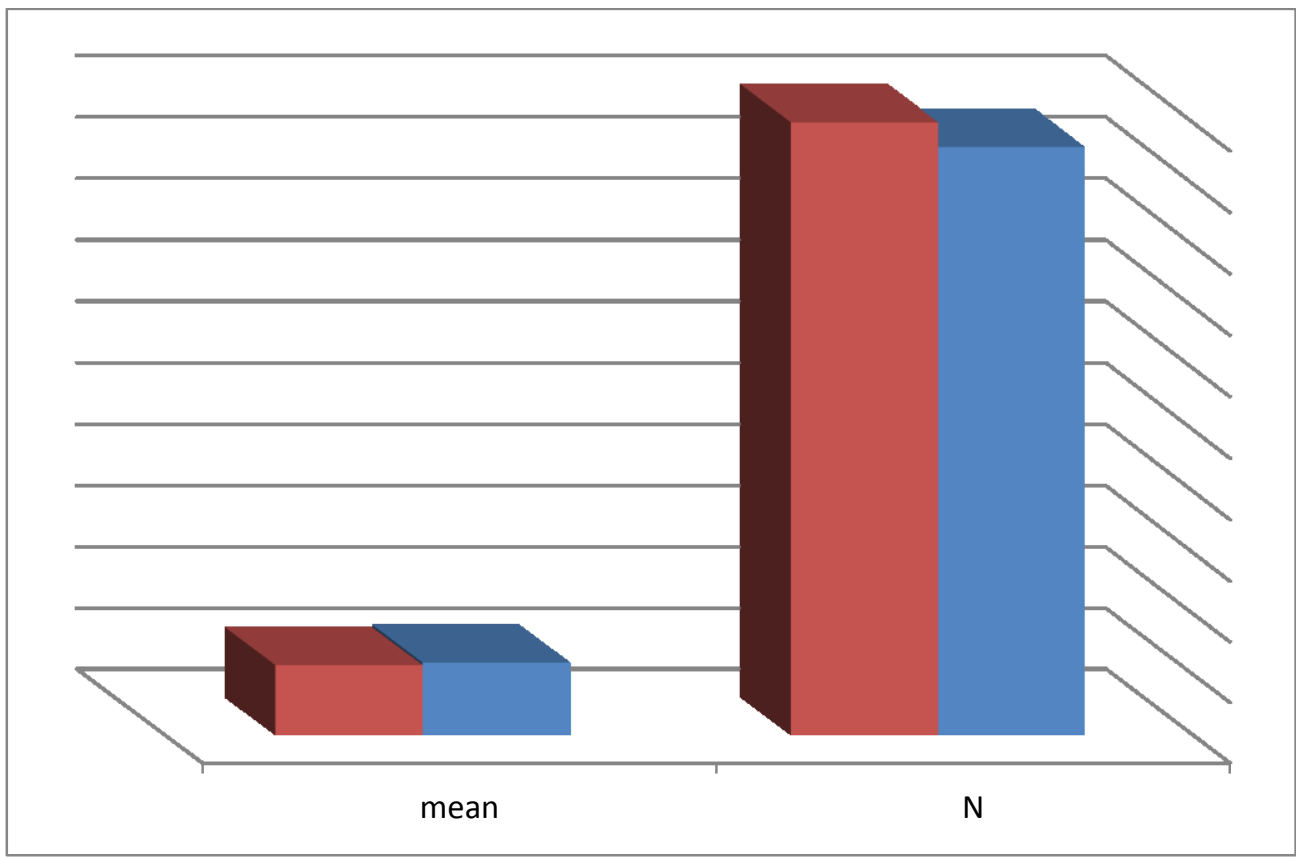

Male monolinguals

Male bilinguals

Fig. 1. Results of t-test and one-way ANOVA for mean scores on male monolinguals and male bilinguals in revised cheek and buss shyness scale.

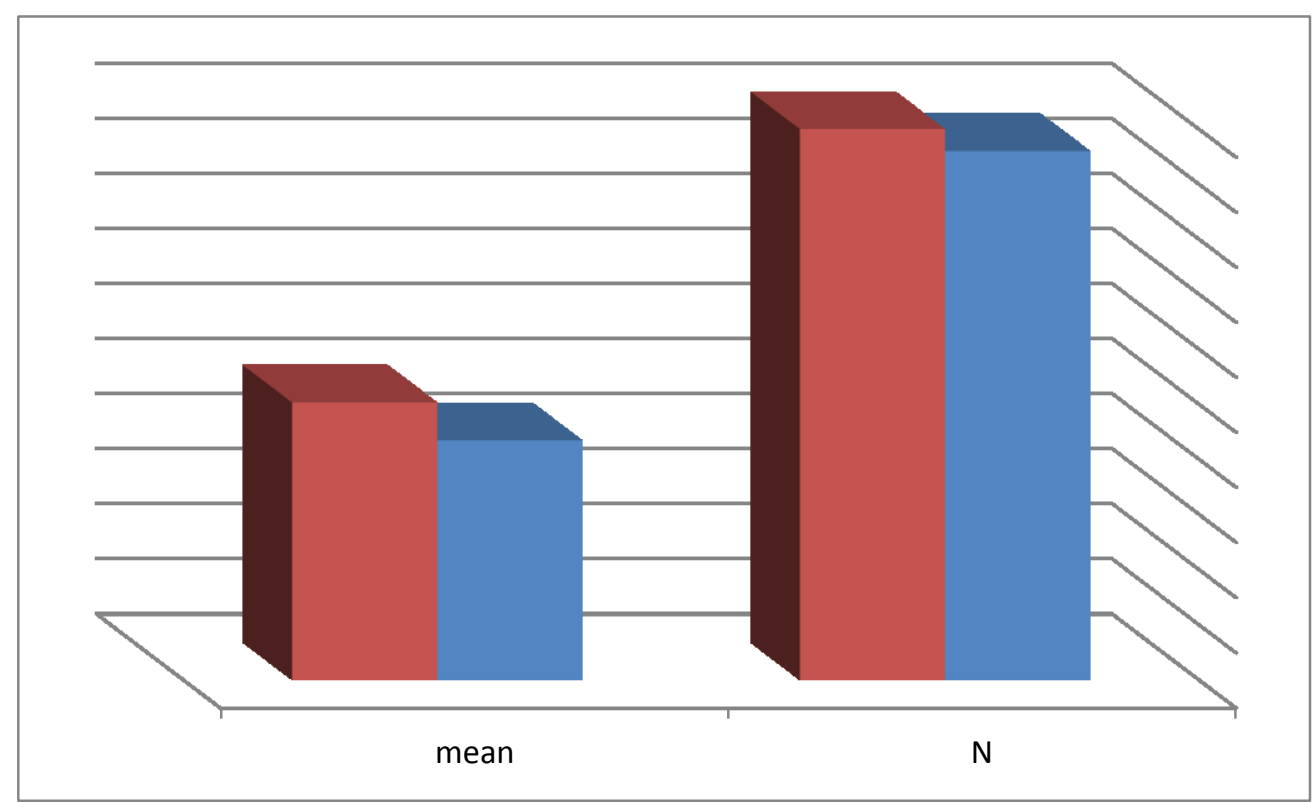

Male monolinguals

Male bilinguals

Fig. 2. Results of t-test and one-way ANOVA for mean scores on male monolinguals and male bilinguals in General English proficiency. 
Regarding statistical analysis, the second hypothesis (Shyness has more effect on bilingual learners.

\section{CONCLUSIONS}

Final results indicated that there's not a statistically significant difference between the shyness level of the male mono and bilinguals. So the first hypothesis was rejected. On the other hand, analysis of data indicated that there is a significant difference between English language proficiency level of male mono and bilingual students because male bilinguals scored higher than male monolinguals. In one study by Crozier (2005), he has mentioned that students were not different in total shyness scores regarding their gender differences; however, there were differences between two out of 14 items in revised cheek and buss shyness scale (RCBS).

\section{References}

[1] Baş G. (2010). An Investigation of the Relationship between Shyness and Loneliness Levels of Elementary Students in a Turkish Sample. International Online Journal of Educational Sciences, 2(2).

[2] Buss A. H. (1980). Self-consciousness and social anxiety (p. 22). San Francisco: WH freeman.

[3] Caspi A., Elder G. H. J., Bem D. J. (1988). Moving away from the world: Life-course patterns of shy children. Developmental Psychology, 24(824); 831.

[4] Cheek J. M., Briggs S. R. (1990). Shyness as a personality trait. Shyness and embarrassment: Perspectives from social psychology, 315-337.

[5] Crozier W. (2005). Measuring shyness: analysis of the Revised Cheek and Buss Shyness scale. Personality and Individual Differences, 38(8); 1947-1956.

[6] Edwards A. W. (2003). Human genetic diversity: Lewontin's fallacy. BioEssays, 25(8); 798-801.

[7] Karbalaei A. (2010). Who is in advantage: a Balanced or Dominant Bilingual. MJAL 2:3 March.

[8] Leary M. R., Schlenker B. R. (1981). The social psychology of shyness: A selfpresentational model. Impression management theory and social psychological research, 335-358.

[9] Maghsoudi M. (2010). The Interaction between Bilingualism, Educational and Social Factors and Foreign Language Leaning in Iran. Language in India, 10(9).

[10] Maleki A. (2011). The Presence of Turkish Accent in the Iranian Turkish Speaking People's Farsi Contrasted with its Absence in Their Speaking English: Minimal Overwhelms Maximal Bilingualism. Journal of Language Teaching \& Research, 2(1).

[11] Merrikhi P. (2012). The Effect of" Bilingualism" on Iranian Pre-university Students' English Grammar Proficiency. Theory and Practice in Language Studies, 2(2); 360-370. 
[12] Sampath K. K. (2005). Effect of bilingualism on intelligence. In Proceedings of the 4th International Symposium on Bilingualism. Cascadilla press.

[13] Stockli G. (2002). Shyness in cultural context: A comparative study of correlates of shyness in school children in Switzerland and China. Psychologie in Erziehung und Unterricht, 49(2); 151-158.

[14] Tanveer M. (2007). Investigation of the factors that cause language anxiety for ESL/EFL learners in learning speaking skills and the influence it casts on communication in the target language. Unpublished thesis). Faculty of education, University of Glasgow.

[15] Zimbardo P. G. (1977). Shyness: what it is, what to do about it. Reading, MA: AddisonWesley Publishers (deutsche Übersetzung 1994: Nur nicht so schüchtern. München: mvg-verlag).

[16] Monirosadat Hosseini, Mohamad Ehsan Taghizadeh, Mohamad Jafre Zainol Abedin, Elham Naseri, International Letters of Social and Humanistic Sciences 6 (2013) 1-12.

[17] Hussein Meihami, Bahram Meihami, International Letters of Social and Humanistic Sciences 7 (2013) 86-95.

[18] Hussein Meihami, International Letters of Social and Humanistic Sciences 8 (2013) $8-23$.

[19] Hussein Meihami, Zeinab Varmaghani, International Letters of Social and Humanistic Sciences 9 (2013) 49-58.

[20] Hussein Meihami, Bahram Meihami, Zeinab Varmaghani, International Letters of Social and Humanistic Sciences 11 (2013) 47-56.

[21] Monirosadat Hosseini, Mohamad Jafre Zainol Abidin, Hamid Kamarzarrin, Mohamad Khaledian, International Letters of Social and Humanistic Sciences 11 (2013) 66-75.

[22] Hussein Meihami, Bahram Meihami, International Letters of Social and Humanistic Sciences 2 (2014) 10-19.

[23] Hussein Meihami, Bahram Meihami, International Letters of Social and Humanistic Sciences 5 (2014) 35-43.

[24] Hussein Meihami, Bahram Meihami, International Letters of Social and Humanistic Sciences 5 (2014) 63-72.

[25] Mohammad Ali Heidari-Shahreza, International Letters of Social and Humanistic Sciences 20 (2014) 14-21. 


\section{APPENDICES}

\section{Appendix I}

\section{Background Questionnaire}

\begin{tabular}{|c|c|c|}
\hline NO. & Question & Answer \\
\hline 1. & نام Name & \\
\hline 2. & سن Age & \\
\hline 3. & جنسيت Gender & Female مونث \\
\hline 4. & نام مدرسه Name of school & \\
\hline 5. & 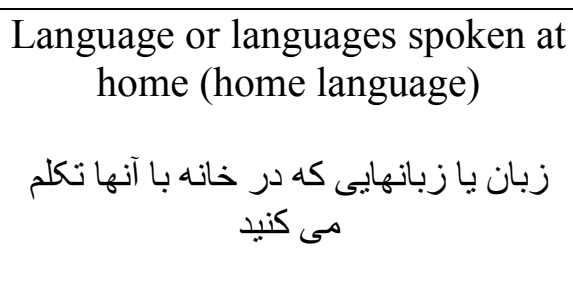 & 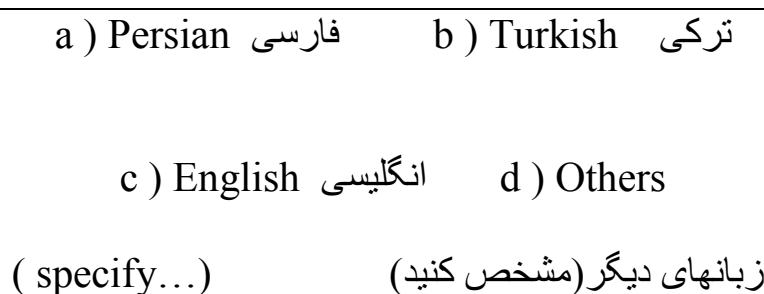 \\
\hline
\end{tabular}

\section{Appendix II}

\section{How Shy Are You?}

Read each item carefully, and decide to what extent it is characteristic of your feelings and behavior. Answer each question by choosing a number from the scale below.

$\mathbf{1}=$ Very uncharacteristic or untrue, strongly disagree

$2=$ Uncharacteristic

$\mathbf{3}=$ Neutral

$\mathbf{4}=$ Characteristic

$5=$ Very characteristic or true, strongly agree

\section{Questions}

1. I feel tense when I'm with people I don't know well.

2. I am socially somewhat awkward.

3. I find it difficult to ask other people for information.

4. I am often uncomfortable at parties and other social functions. 
5. When in a group of people, I have trouble thinking of the right things to say.

6. It takes me long to overcome my shyness in new situations.

7. It is hard for me to act natural when I am meeting new people.

8. I feel nervous when speaking to someone in authority.

9. I have doubts about my social competence.

10. I have trouble looking someone right in the eye.

11. I feel inhibited in social situations.

12. I find it hard to talk to strangers.

13. I am shyer with members of the opposite sex.

Appendix III extracted from Transparent Language: http://www.transparent.com/

\section{Language Proficiency Test}

Full name:

Gender:

\section{Part I: English Grammar}

Select the best answer for each question.

1. Juan in the library this morning.
A. is study
B. studying
C. is studying
D. are studying

2. Alicia, the windows please. It's too hot in here.
A. opens
B. open
C. opened
D. will opened

3. The movie was the book.
A. as
B. as good
C. good as
D. as good as

4. Eli's hobbies include jogging, swimming, and
A. to climb mountains
B. climb mountains
C. to climb
D. climbing mountains

5. Mr. Hawkins requests that someone
A. sent
B. sends
C. send
D. to send the data by fax immediately.

6. Who is , Marina or Sachiko?
A. tallest
B. tall
C. taller
D. the tallest

7. The concert will begin
A. in
B. on
C. with
D. about fifteen minutes.

8. I have only a Christmas cards left to write.
A. few
B. fewer
C. less
D. little

9. Each of the Olympic athletes for months, even years.
A. have been training
B. were training
C. has been training
D. been training 
10. Maria never late for work.
A. am
B. are
C. were
D. is

11. The company will upgrade
A. there
B. their
C. it's
D. its computer information systems next month.

12. Cheryl likes apples,
A. so
B. for
C. but
D. or she does not like oranges.

13. You were the New York office before 2 p.m.
A. suppose call
B. supposed to call
C. supposed calling
D. supposed call

14. When I graduate from college next June, I
A. will have been
B. have been
C. has been
D. will have a student here for five years.

15. Ms. Guth rather not invest that money in the stock market.
A. has to
B. could
C. would
D. must

\section{Part II: English Grammar}

Select the one underlined word or phrase that is incorrect.

16. The majority to the news is about violence or scandal.
A. The
B. to
C. news
D. violence

17. Takeshi swimmed one hundred laps in the pool yesterday.
A. swimmed
B. hundred
C. in
D. yesterday

18. When our vacation, we plan to spend three days scuba diving.
A. When
B. plan
C. days
D. diving

19. Mr. Feinauer does not take critical of his work very well.
A. does
B. critical
C. his
D. well

20. Yvette and Rinaldo send e-mail messages to other often.
A. and
B. send
C. other
D. often

21. Mr. Olsen is telephoning a American $\underline{\operatorname{Red}}$ Cross for help.
A. is
B. a
C. Red
D. for

22. I had a enjoyable time at the party last night.
A. a
B. time
C. at
D. last

23. The doctor him visited the patient's parents.
A. The
B. him
C. visited
D. patient's 
24. Petra intends to starting her own software business in a few years.
A. intends
B. starting
C. software
D. few

25. Each day after school, Jerome run five miles.
A. Each
B. after
C. run
D. miles

26. He goes never to the company softball games.
A. never
B. the
C. softball
D. games

27. Do you know the student who books were stolen?
A. Do
B. know
C. who
D. were

28. Jean-Pierre will spend his vacation either in Singapore nor the Bahamas.
A. will
B. his
C. nor
D. Bahamas

29. I told the salesman that I was not interesting in buying the latest model.
A. told
B. that
C. interesting
D. buying

30. Frederick used work for a multinational corporation when he lived in Malaysia.
A. used work
B. multinational
C. when
D. lived in

\section{Part III. English Vocabulary}

Select the best answer.

31. The rate of has been fluctuating wildly this week.
A. money
B. bills
C. coins
D. exchange

32. The bus arrives late during bad weather.
A. every week
B. later
C. yesterday
D. always

33. Do you where the nearest grocery store is?
A. know
B. no
C. now
D. not

34. Jerry Seinfeld, the popular American comedian, has his audiences

A. putting too many irons in the fire B. keeping their noses out of someone's business $\mathrm{C}$. rolling in the aisles D. going to bat for someone

35. The chairperson will members to the subcommittee.
A. appoint
B. disappoint
C. appointment
D. disappointed

36. The critics had to admit that the ballet was superb.
A. procrastinate
B. performance
C. pathology
D. psychosomatic

37. Peter says he can't
A. angel
B. across
C. accept our invitation to dinner tonight.

38. We were friends in that strange but magical country.
A. upon
B. among
C. toward
D. in addition to 
39. The hurricane caused damage to the city.
A. extend
B. extended
C. extensive
D. extension

40. Many cultures have special ceremonies to celebrate a person's of passage into adulthood.
A. right
B. rite
C. writ
D. write

\section{Part IV. English Reading Comprehension}

\section{Select the best answer.}

\section{Directions to Erik's house}

Leave Interstate 25 at exit 7S. Follow that road (Elm Street) for two miles. After one mile, you will pass a small shopping center on your left. At the next set of traffic lights, turn right onto Maple Drive. Erik's house is the third house on your left. It's number 33, and it's white with green trim.

41. What is Erik's address?
A. Interstate 25
B.2 Elm Street
C.13 Erika Street
D.33 Maple Drive

42. Which is closest to Erik's house?
A. the traffic lights
B. the shopping center
C. exit $7 \mathrm{~S}$
D. a greenhouse

Date: May 16, 1998

To: Megan Fallerman

From: Steven Roberts

Subject: Staff Meeting

Please be prepared to give your presentation on the monthly sales figures at our upcoming staff meeting. In addition to the accurate accounting of expenditures for the monthly sales, be ready to discuss possible reasons for fluctuations as well as possible trends in future customer spending. Thank you.

43. The main focus of the presentation will be
A. monthly expenditures
B. monthly salary figures
C. monthly sales figures
D. Staffmeeting presentations

44. Who will give the presentation?
A. the company president
B. Megan Fallerman
C. Steven Roberts
D. future customers

\section{The B\&B Tour}

Spend ten romantic days enjoying the lush countryside of southern England. The counties of Devon, Dorset, Hampshire, and Essex invite you to enjoy their castles and coastline, their charming bed and breakfast inns, their museums and their cathedrals. Spend lazy days watching the clouds drift by or spend active days hiking the glorious hills. These fields were home to Thomas Hardy, and the ports launched ships that shaped world history. Bed and breakfasts 
abound, ranging from quiet farmhouses to lofty castles. Our tour begins August 15. Call or fax us today for more information 1-800-222-XXXX. Enrollment is limited, so please call soon.

45. Which of the following counties is not included in the tour?
A.
Devon
B. Cornwall
C. Essex
D. Hampshire

46. How many people can go on this tour?
A. 10
B. an unlimited number
C. $2-8$
D. a limited number

47. What can we infer about this area of southern England?
A. The region has lots of vegetation.
B. The coast often has harsh weather.
C. The sun is hot and the air is dry.
D. The land is flat.

Anna Szewczyk, perhaps the most popular broadcaster in the news media today, won the 1998 Broadcasting Award. She got her start in journalism as an editor at the Hollsville County Times in Missouri. When the newspaper went out of business, a colleague persuaded her to enter the field of broadcasting. She moved to Oregon to begin a master's degree in broadcast journalism at Atlas University. Following graduation, she was able to begin her career as a local newscaster with WPSU-TV in Seattle, Washington, and rapidly advanced to national television. Noted for her quick wit and trenchant commentary, her name has since become synonymous with Good Day, America! Accepting the award at the National Convention of Broadcast Journalism held in Chicago, Ms. Szewczyk remarked, "I am so honored by this award that I'm at a total loss for words!" Who would ever have believed it?

48. What is the purpose of this announcement?

A. to invite people to the National Convention of Broadcast Journalism B. to encourage college students to study broadcasting C. to recognize Ms. Szewczyk's accomplishments D. to advertise a job opening at the Hollsville County Times

49. The expression "to become synonymous with" means
A. to be the same as.
B. to be the opposite of.
C. to be in sympathy with.
D. to be discharged from.

50. What was Ms. Szewczyk's first job in journalism?
A. She was a T.V. announcer in Washington.
B. She was a newscaster in Oregon.
C. She was an editor for a newspaper in Missouri.
D. She was a talk show host in Chicago. 